\title{
PERLINDUNGAN HUKUM ATAS SAKSI KORBAN TINDAK PIDANA PERKOSAAN BAGI ANAK-ANAK DI BAWAH UMUR
}

Oleh :

\author{
Erly Pangestuti, SH.,M.H \\ sherly8080@gmail.com
}

\begin{abstract}
Abstraksi :
Kejahatan perkosaan dapat mengakibatkan terganggunya perkembangan mental dan kehidupan korban dimasa depannya yang akan terbawa seumur hidupnya. Di negara kita sampai pada saat ini belum ada perlindungan hukum yang melindungi secara khusus terhadap korban tindak pidana perkosaan sehingga dalam memberi perlindungan hanya tepancang pada pasal 285 KUHP yang pada saat ini sudah dinilai kurang sesuai lagi dengan kemajuan dan perkembangan pada masyarakat kita sehingga perlu adanya perubahan. Mengingat dalam pasal 285 KUHP sanksi yang diberikan dinilai sangat ringan jika dibandingkan dengan penderitaan korban yang ditanggung seumur hidup dan mempengaruhi masa depannya kelak korban dewasa. Pemberian pidana atau hukuman yang ringan pada pelaku perkosaan tidak akan membuat pelaku jera, bahkan bagi mereka yang sudah terbiasa keluar masuk penjara tidak akan menjadi suatu beban. Hal tersebut bisa kita ketahui dengan semakin meningkatnya kasus perkosaan yang terjadi dimana-mana, dan perkosaan sulit diduga sebelumnya karena pelaku biasanya orang yang dekat dengan korban atau yang tidak diketahui sebelumnya bila seseorang mempunyai kelainan dalam seksnya.
\end{abstract}

\section{Kata Kunci : Perkosaan, Korban, Anak-anak.}

\section{A. Latar Belakang Permasalahan}

Tindak pidana pemerkosaan merupakan suatu kejahatan yang sangat mendapat perhatian di masyarakat. Kasus tersebut merupakan kejahatan klasik yang akan selalu mengikuti perkembangan kebudayaan manusia itu sendiri yang sudah ada sejak dahulu serta berkembang setiap saat walaupun mungkin tidak terlalu berbeda jauh dengan sebelum-sebelumnya. Hal ini merupakan suatu kemajuan yang luar biasa yang terdapat dalam segala bidang kehidupan masyarakat,serta sangat memerlukan pertimbangan-pertimbangan yang logis serta berhati-hati agar modernisasi yang bertujuan akan memberikan kenikmatan dan ketentraman menjadi berbalik arah serta menjadi bumerang akan timbulnya 
kejahatan. Sehubungan dengan perkembangan ini tentu berpengaruh terhadap kehidupan sosial dan tata nilai yang berlaku dalam masyarakat serta norma yang ada,yaitu dengan munculnya pola-pola baru yang berarti lenyapnya pola-pola lama dan merubah struktur serta cara berpikir masyarakat berdasarkan keadaan yang ada. Hal inilah mengakibatkan ketegangan-ketegangan maupun problem-problem sosial seperti perasaan tidak aman,perasaan kurang mampu,perasaan bermusuhan dan konflik yang merupakan faktor penting timbulnya suatu kejahatan.

Modernisasi dengan perkembangan teknologi modern diharapkan bisa membawa kesenangan,kemudahan dan ketentraman dalam kehidupan sosial masyarakat tidaklah demikian karena kejahatan turut berkembang pula seiring dengan kemajuan tersebut. Justru pada saat ini kejahatan semakin tumbuh subur dan beragam nampak dalam kehidupan masyarakat,tidak saja dalam masyarakat yang sedang berkembang namun juga dalam masyarakat yang maju.Perkembangan kejahatan yang bersamaan dan berkembangnya masyarakat ini adalah suatu hal yang tidak kita inginkan,namun merupakan kenyataan yang tidak dapat kita hindarkan dari hasil samping modernisasi. Dari hal ini dapatlah dipastikan bahwa kemajuan membawa pengaruh terhadap jumlah atau jenis kejahatan baru yang terjadi dan sangat menonjol adalah cara dilakukannya kejahatan lebih rapi dan terencana. Kejahatan ini merupakan suatu permasalahan yang sulit dihapus selama manusia mendiami di bumi ini.

Kitab Undang-undang Hukum Pidana (selanjutnya disebut KUHP) khususnya dalam bab II tentang kejahatan telah disebutkan dengan bermacammacam jenis kejahatan kesusilaan ini meliputi,pornografi,persetubuhan,perzinaan dan pemerkosaan. Saat ini kasus-kasus kejahatan kesusilaan yang berwujud pemerkosaan terhadap anak semakin meningkat dan sangat meresahkan kita semua. Kecemasan dan kekhawatiran tersebut adalah sangat beralasan,hal mana dapat diketahui dari berita-berita mas media maupun elektronik hampir setiap terbitnya memuat berita pemerkosaan dan sebagainya. Pemerkosaan terhadah anak dibawah umur ini meresahkan tidak saja para orang tua namun juga para tokoh agama dan tokoh masyarakat.

Penanganan dari hukum atas perkosaan terhadap anak ini, yang utama adalah penegak hukum yang berupa penindakan terhadap pelaku,secara umum 
Untuk membuktikan bahwa telah terjadi perkosaan,harus dipenuhi unsur-unsur pasal 285 KUHP,yaitu :

1. Telah terjadi persetubuhan antara korban dengan terdakwa.

2. Korban bukan istri terdakwa.

3. Persetubuhan itu dilakukan dengan kekerasan atau ancaman,kekerasan yang bertentangan dengan kemampuan korban.

Saksi kejahatan perkosaan sangatlah berat namun ada beberapa kasus perkosaan,hukuman yang diberikan kepada pelaku adalah ringan,walaupun tindak kejahatan tersebut telah memenuhi unsur-unsur yang tercantum dalam pasal 285 KUHP tersebut. Bila dibandingkan dengan akibat yang harus ditanggung oleh korban seumur hidupnya yang menimbulkan psikologis yang berat dan lama. Trauma yang sangat berat dan lama ini akan berlangsung dan mempengaruhi masa depannya.

Pemerkosaan telah disebutkan dalam pasal 285 KUHP yaitu "Barang siapa dengan kekerasan atau ancaman kekerasan memaksa seseorang wanita bersetubuh dengan dia diluar perkawinan,diancam karena melakukan perkosaan,diancam dengan pidana penjara paling lama 12 tahun.” Kejahatan perkosaan dalam KUHP dirumuskan dalam buku II bab XIV pasal 285,dengan ancaman pidana yang cukup berat,menandakan sifat perbuatan pidana. Kejahatan perkosaan ini sangat menganggu ketentraman masyarakat.

\section{B. Perumusan Masalah}

Berkenaan dengan latar belakang tersebut diatas, maka peneliti merumuskan penelitian dengan permasalahan sebagai berikut :

1. Sudah adakah perlindungan atas saksi korban terhadap kejahatan kesusilaan?

2. Langkah apa sajakah yang bisa diambil oleh korban atau walinya apabila perlindungan hukum tidak terpenuhi?

\section{Tujuan Penulisan}

Sesuai permasalahan yang diuraikan, penulis merumuskan tujuan penelitian ini sebagai berikut : 
1. Untuk mengetahui apakah sudah ada perlindungan hukum atas saksi korban tindak pidana perkosaan bagi anak-anak di bawah umur.

2. Untuk mengetahui langkah apa saja yang bisa diambil oleh korban atau walinya apabila perlindungan hukum tidak terpenuhi.

\section{Metodologi Penelitian}

Guna memperoleh data yang valid peneliti menggunakan metode diskriptif analis yaitu menyajikan keadaan yang sebenarnya atas penemuan dalam penelitian ini serta menganalisa adanya permasalahan yang ditemukan tentang perlindungan hukum atas saksi korban tindak pidana perkosaan bagi ank-anak dibawah umur. Data sekunder yaitu pengumpulan bahan-bahan dengan menggunakan cara seperti membaca buku-buku, arsip-arsip,majalahmajalah,dokumentasi-dokumentasi dan lain sebagainya. Studi Kepustakaan ini penulis lakukan untuk mencari konsepsi-konsepsi, teori-teori ataupun pandangan-pandangan yang relevan dengan permasalahan yang ada. Bahan hukum yang akan dipakai dalam penelitian meliputi bahan hukum primer terdiri dari Kitab Undang-undang Hukum Pidana, Kitab Undang-undang Acara Pidana, Undang-undang Peradilan Anak. Sedangkan bahan sekuner meliputi buku-buku dan tulisan-tulisan yang berkaitan dengan permasalahan yang dibahas ,

\section{Tinjauan Umum Tentang Kejahatan Perkosaan Terhadap Anak.}

Tindak Pidana" adalah salah satu istilah dalam bahasa Indonesia yang merupakan terjemahan dari bahasa Belanda yaitu "Sstrafbaarfeit". Dalam Ilmu Hukum Pidana di Indonesia,dipakai dengan beberapa istilah lain yang pengertiannya sama dengan Strafbaarfeit. Istilah-istilah tersebut adalah Peristiwa pidana, Perbuatan pidana, Pelanggaran pidana, Perbuatan yang dapat dihukum. diantara istilah tersebut dalam masyarakat Indonesia lebih dikenal dengan istilah tindak pidana. Dalam membicarakan istilah tindak pidana ini, tidak akan terlepas daripada unsur tindak pidana. Sehubungan dengan unsur tindak pidana ada dua aliran untuk mengkhajinya,yaitu aliran monistis dan aliran dualistis. Aliran Monistis tidak memisahkan unsur yang melekat pada 
perbuatannya (Criminal act/perbuatan pidana) dengan unsur yang melekat pada pelaku Criminal responbility/pertanggungan jawab pelaku). Jadi aliran monistis memandang semua syarat untuk penjatuhan pidana sebagai unsur pidana.

Kata perkosaan berasal dari kata dasar "Perkosa"menurut Daryanto S.S yang berarti gagah perkoso atau gagah berani,memperkosa berarti menggagahi atau memaksa. Begitu kita mendengar kata perkosaan, secara langsung atau tidak langsung timbul rasa muak,benci dan jijik pada pelaku,benci dan kasihan. Benci kepada ulah si pelaku,kasihan kepada nasib si kurban perkosaan,maka terbayanglah ulah tingkah laku seorang pria terhadap seorang wanita secara paksa memuaskan hawa nabsunya.Sesungguhnya kata perkosaan ini tidak hanya menyangkut pemaksaan akan hubungan seksual saja,akan tetapi berbagai perkosaan dapat terjadi. Seperti pada perkosaan terhadap hak asasi. Misalnya hak asasi dalam hal kebebasan berbicara,berpendapat atau kebebasan lain yang menyangkut tingkah laku manusia dalam nilai budaya masyarakat. Hak-hak yang demikian memang seharusnya dimiliki dan diberikan kepada manusia berdasarkan martabatnya sebagai manusia.Yang menjadi permasalahan di dalam penelitian ini adalah tentang perkosaan yang berhubungan dengan persetubuhan.

Tindak pidana perkosaan merupakan bagian dari delik kesusilaan yang termuat dalam kitab undang-undang Hukum Pidana dalam Buku II Bab XIV pasal 285, yang menyebutkan "Barang siapa dengan kekerasan atau ancaman kekerasan memaksa seseorang wanita bersetubuh dengan di luar perkawinan diancam karena melakukan perkosaan dengan pidana penjara paling lama dua belas tahun.

\section{E. Batasan Usia Anak}

Dalam undang-undang No.4 Tahun 1979 tentang kesejahteraan anak membatasi pengertian anak adalah "seseorang yang mencapai umur 21 tahun dan belum pernah kawin"ini berarti anak yang berumur dibawah usia tersebut tetapi telah kawin tidak termasuk sebagai anak. Sedangkan berdasarkan undang-undang NO.3 Tahun 1997 tentang peradilan anak dalam pasal 1 ayat 1menyatakan bahwa anak adalah orang dalam perkara anak Nakal telah mencapai umur 8 (delapan) tahun tetapi belum mencapai 18 tahun tetapi telah 
kawin tidak dianggap sebagai anak. Sedangkan di dalam undang-undang perkawinan No.1 tahun 1974,dalam pasal 6 ayat 2 menyebutkan bahwa seseorang dianggap sudah dewasa atau sudah mampu kawin jika sudah berumur 21 (duapuluh satu) tahun. Karena pada usia ini mereka sudah dianggap dewasa dan tidak perlu ijin orang tua untuk melakukan perkawinan. Namun dalam pasal 7 undang-undang NO.101974 memperjelas lagi bahwa laki-laki yang telah mencapai umur 16 tahun boleh melaksanakan perkawinan asalkan mendapat ijin dari orang tuanya. Dan bagi mereka yang ada dibawah umur tersebut berarti belum boleh melaksanakan perkawinan sekalipun mendapatkan ijin dari orang tuanya.

Dalam KUHP tidak kita jumpai pengertian anak (anak dibawah umur) namun dalam KUHP dapat satu pasal yang memberikan batas umur dalam pertanggung jawabbagi anak yang belum dewasa,sebelum usia 16 tahun.Yaitu pasal 45 KUHP yang menyebutkan "jika seorang yang belum dewasa di tuntut karena perbuatan yang dikerjakannya ketika umur enam belas tahun.

\section{E. Faktor-Faktor Terjadinya Perkosaan Terhadap Anak}

Untuk mengetahui terjadinya kejahatan perkosaan terhadap anak di bawah umur dapat dikatakan agak sulit, karena banyak faktor yang mempengaruhinya seperti, faktor pribadi,lingkungan,pendidikan,kesempatan dan lain sebagainya. Masalah sebab-sebab kesejahteraan ini secara luas diselidiki dan dipelajari oleh kriminologi dalam salah satu bagian pokoknya yaitu etiologi kriminal. Untuk mencari sebab-sebab terjadinya kejahatan ada beberapa faktor yang mempengaruhi timbulnya "GW Bawengan"pada pandangannya dalam aliran sosiologis mengemukakan bahwa kejahatan adalah hasil kontak dari lingkungan sekitar individu. Kejahatan merupakan perbuatan manusia yang merupakan hasil dari unsur-unsur individual. Dan lingkungan."perbuatan"sendiri menurut bawengan adalah hasil kontak antara unsur-unsur phisis dan psikis disatu pihak dengan unsur lingkungan,baik lingkungan alam maupun lingkungan masyarakat di pihak lain. Dari hal ini memang suatu kenyataan yang tidak dapat kita pungkiri bahwa lingkungan sekitar individu sangat berperan dalam bentuk suatu individu tersebut. 
Dari pandangan bawengan ini,dapatlah diketahui bahwa suatu kejahatan tidak hanya ditimbulkan oleh satu faktor saja,melainkan disebabkan oleh kombinasi dari berbagai faktor yang satu dengan yang lain saling pengaruh mempengaruhi dan saling berkaitan yang tidak dapat dipisahkan. Beberap faktor tersebut adalah :

\section{Usia}

Seseorang yang sudah menjadi dewasa tumbuh dan berkembang,perasaannya berubah terutama dalam bidang seksual. Perasaan ini membawa seseorang menyukai akan benda-benda yang indah dan menarik.Pergaulannya pun makin luas dan meningkat pada lingkungan yang lebih luas lagi,orang mulai tertarik dengan lawan jenisnya,rasa tertarik semakin besar dengan meningkatnya usia,sehingga mulai merasakan suatu kebutuhan untuk menyalurkan rasa tertariknya pada lawan jenisnya.Bila keadaan ini tidak dapat terpenuhi dan tidak dapat disalurkan dengan benar dan diimbangi oleh kesiapan dan kematangan mental,sedangkan mereka membutuhkan penyaluran untuk memenuhi rasa tertariknya pada lawan jenis,maka timbullah penyimpangan-penyimpanagn tingkah laku.

Dalam menjalankan kegiatan sebagai penyalur rasa tertarik terhadap lawan jenis, mereka melakukan dengan anak yang masih berada dalam usia dibawah umur,karena mempunyai daya tahan phisik yang masih lemah disamping anak masih adalah sarana pemuasan nafsu seks yang aman.

\section{Pendidikan}

Tidak semua pelaku mempunyai pendidikan yang rendah,akan tetapi sesuatu hal yang tidak dapat disangkal lagi,bahwa tingkat pendidikan yang rendah pada diri seseorang dapat berpengaruh terhadap jiwa,cara kerja dan alam berpikirnya. Pendidikan disini tidak hanya pendidikan yang diperoleh di bangku sekolah namun disini pendidikan yang diperoleh dan dipelajari dari lingkungan tempat tinggal juga sangat mempengaruhi akan perkembangan jiwa seseorang.Terutama pendidikan dalam keluarga lebih sangat berperan aktif dan sangat penting dalam bentuk pola bertingkah laku dan jiwa seseorang dalam cara bekerja dan berpikir. 


\section{Lemahnya Penghayatan Terhadap Agama}

Agama merupakan unsur pokok dalam kehidupan manusia dan merupakan kebutuhan spiritual. Agama selalu mengajarkan kebajikan.Menjahui kejahatn dan perbuatan terlarang lain pihak merupakan rel kehidupan bermasyrakat. Selain itu juga membukakan hati setiap manusia agar cinta terhadap sesama,sehingga manusia benar-benar mendalami dan menghayati makna agama,yang diharuskan menjadi manusia yang berbudi pekerti baik.Tetapi jika agama hanya dipakai sebagai simbol,tidak mustahil orang tersebut lemah imannya sehingga mudah melakukan hal-hal yang meyesatkan.Seperti halnya melakukan kejahatan perkosaan.Seperti yang dikatakan oleh kraus bahea "pengasingan diri terhadap Tuhan serta pandangan hidup yang berdasarkan agama merupakan dasar hitam bagi perkembangan kejahatan"

\section{Pemuasan Biologis Semata}

Pelaku kejahatan perkosaan terhadap anak karena adanya penyimpangan seksual dari pelaku lebih cenderung puas bila sudah melakukan hubungan seks dengan anak yang berusia dibawah umur.Apabila hal ini memang melatarbelakangi maka keadaan seperti ini akan semakin meningkat dan setiap anak dibawah umur akan semakin potensial sebagai obyeknya.Keadaan sulit seperti ini sulit diduga sebelumnya,karena orang cenderung tidak memiliki prasangka buruk pada orang lain,terutama dugaan sebagai orang pengidap kelainan seksuil.Selain itu biasanya pelaku pemerkosaan dalam melampiaskan nafsunya mereka cenderung memilih anak-anak yang sudah mereka kenal secara dekat sehingga mereka lebih mudah untuk membujuknya.

\section{Faktor Lingkungan}

Lingkungan mempunyai pengaruh yang besar terhadap perkembangan jiwa seseorang baik sebagai individu maupun sebagai mahkluk sosial. Pengaruh yang besar pada tingkah laku dan perbuatan manusia, hal semacam ini semakin nyata dengan semakin mudah ditemukannya gambar-gambar porno,tulisantulisan cabul, Video Porno yang diakses melalui internet. Apabila hal-hal tersebut sampai dibaca dan dilihat oleh orang-orang yang mempunyai mental 
dan kepribadian yang kurang matang,maka dampak negatifnya secara langsung akan mempengaruhi jiwa dan jalan pikiran seseorang.

\section{Faktor Kesempatan}

Faktor kesempatan mulai suatu peluang yang bisa memacu seseorang melakukan tindak kejahatan. WA Bonger dalam bukunya Pengantar Tentang Kriminologi mengatakan bahwa "sebagian besar dari kejahatan seksual adalah kejahatan karena kesempatan (Jalan yang sunyi dan lain-lain). Tidak adanya atau kurangnya kontrol keamanan yang baik memacu terjadinya kejahatan atau perkosaan dilingkungan tersebut. Jadi tidak atau kurangnya kontrol keamanan yang mantap,berarti merupakan peluang yang baik untuk seseorang dalam melalukan kejahatan.

\section{F. Kejahatan Perkosaan Terhadap Anak}

Kejahatan perkosaan merupakan suatu perbuatan yang menimbulkan keresahan,kecemasan dan ketidaktenangan dalan kehidupan masyarakat. Selain itu perbuatan perkosaan membawa suatu dampak yang sangat berat bagi korban baik secara phisik maupun psikis. Secara phisik korban akan mengalami luka dan sakit karena mereka masih seorang anak-anak yang belum mampu untuk disetubuhi. Sedangkan secara psikis akan memberikan suatu dampak yang sangat berat sekali,diantaranya korban akan mengalami suatu trauma yang berat dan panjang dalam waktu yang lama bahkan akan mempengaruhi langkah masa depannya seumur hidup, korban akan selalu terbawa dalam trauma dan ketakutan akan lawan jenisnya atas kejadian tersebut,jadi pendiam atau bahkan terbawa dalam mimpi yang merupakan bentuk dari rasa takutnya.

Di dalam KUHP sendiri juga memberikan suatu ancaman hukuman yang tidak ringan pula atas kejahatan perkosaan tersebut.Seperti yang tercantum dalam Buku II Bab XIV pasal 285 yang memberikan ancaman hukuman yang cukup berat yaitu selama-lamanya 12 tahun. Walaupun dalam pasal ini memberikan suatu ancaman hukuman yang cukup berat namun dalam praktiknya penjatuhan pidana atas kejahatan perkosaan terhadap terdakwa ternyata jauh lebih ringan bila dibandingkan daripada besarnya ancaman pidana 
dalam pasal 285 tersebut,apalagi bila ditinjau atau dinilai dengan dampak yang harus dialami oleh korban.

Sedangkan perkosaan terhadap anak yang termasuk ketentuan pasal 285 KUHP dan melakukan persetubuhan dengan wanita yang bukan istrinya yang umurnya belum 15 tahun,menurut pasal 63 KUHP maka pelakunya hanya dikenakan pidana yang memuat ancaman pidana pokok yang paling berat. Penanganan hukum atas kejahatan perkosaan terhadap anak,yang utama adalah penegak hukum berupa penindakan terhadap pelaku. Secara umum kejahatan perkosaan yang dilandasi oleh pasal 285 KUHP,bahwa telah terjadi perkosaan dengan segalaunsur-unsurnya,yang mana dalam praktiknya untuk membuktikannya sering mengalami kesulitan. Karena terdakwa sudah mempersiapkan segala dalih untuk membela diri.

Oleh karena itu tugas dari seorang penegak hukum jaksa penuntut umum sangatlah dituntut perannya. Dalam memberikan dakwaan seorang jaksa penuntut umum haruslah bersifat menjerat dengan harapan terdakwa agar tidak lolos dari dakwaan dengan jalan mengemukakan bukti-bukti yang kuat. Pada prinsipnya suatu tatanan hukum diciptakan untuk memberikan perlindungan. Sehingga hukum secara hakiki harus pasti sebagai pedoman kelakuan dan adil karena pedoman kelakuan itu harus menunjang suatu tatanan yang wajar.Karena bersifat adil dan dilaksanakan dengan pasti hukum dapat menjalankan fungsinya.

Hukum hendaknya harus mengacu pada hak azasi manusia (HAM) karena hukum bertujuan untuk melindungi hak-hak rakyat,sehingga rakyat merasa aman,hak-haknya terlindungi dan dapat memperjuangkan kepentingannya yang sah secara damai.

Mendapatkann keadilann dan perlindungan hukum merupakan hak daripada setiap orang,sehingga suatu keharusan yang harus dipenuhi oleh hukun untuk menyelesaikan suatu sengketa.Masyarakat berhak menyelesaikan konflik atau sengketa yang terjadi pada dirinya melalui pengadilan.Pengadilan juga harus memberikan keadilan yang seadil-adilnya,sehingga masyarakat mempunyai motivasi dan mengakui bahwa pengadilan sebagai sarana untuk menyelesaikan sengketa dan memberikan perlindungan yang baik. 
Namun demikian keadilan yang diharapkan oleh masyarakat tidak selamanya bisa dinikmati setiap orang. Keadilan diharapkan seakan sulit dirasakan oleh rakyat miskin.Karena pada kenyataannya ada kelompok-kelompok sosial tertentu yang merasa diuntungkan,dan mendapat perlakuan yang relatif lebih mudah apabila dibandingkan dengan kelompok-kelompok sosial lainya,seperti proses peradilan yang menyangkut orang-orang yang menjabat,kaya dan berduit,daripada mereka yang terkategori miskin dan tidak mampu.Padahal keadilan yang diorientasikan diatas mestinya merata dan berlaku bagi semua golongan atau kelompok sosial,tanpa adanya suatu pembeda-bedaan. Dengan adanya kenyataan seperti inilah sehingga membuat orang-orang yang miskin dan tidak mampu,cenderung untuk bersikap menerima kenyataan tanpa suatu keberadaan untuk membela diri yang menuntut keadilan sebagai haknya. Seperti halnya perkosaan apabila pelakunya kebetulan orang yang berduit atau anak orang yang mampu,maka mereka cenderung menutup permasalahan dengan menggunakan uang yang nilainya tidak seimbang dengan dampak yang harus ditanggung oleh korban.

Seperti yang dikutip oleh Bambang Sunggono dari bukunya Mulyana W.Kusumah.Hukum dan Hak azasi manusia,mengatakan bahwa pada umumnya orang-orang yang berpunya saja yang dapat menikmati pelayanan hukum yang baik atau dengan perkataan lain,pengadilan tidak diperuntukkan semua lapisan masyarakat.

Kemiskinan yang di derita oleh seseorang ternyata mempunyai dampak yang sangat besar terhadap penegak hukum,terutamadalam kaitannya dengan usaha untuk mempertahankan apa yang menjadi haknya.Sedangkan bagi mereka yang kaya,mereka lebih dekat dengan kekuasaan yang pada saat bersamaan mengidentifikasikan kekuasaan dengan keadilan.

Terlepas dari hal kemiskinan dan kekayaan ini,perlindungan hukum bagi saksi korban tindak pidana perkosaan sendiri,dapat dinilai kurang memberikan perlindungan..Penjatuhan hukuman yang berkisar antara 3 (tiga)tahun di nilai sangatlah jauh lebih ringan jika dibandingkan dengan dampak yang harus dialami korban yang tidak dapat dinilai dengan apapun. Pemberian hukuman yang ringan ini tidak akan membuat pelaku merasa kapok untuk tidak mengulangi perbuatannya lagi,serta bagi mereka yang sudah biasa keluar masuk 
penjara hukuman yang ringan akan dianggap enteng dan tidak menjadi suatu beban. Hal ini terbukti dengan semakin meningkatnaya kasus-kasus perkosaan yang terjadi saat ini di mana-mana.

Perlindungan hukum atas saksi korban kejahatan perkosaan sampai pada saat ini secara khusus belum ada. Jadi dalam memberi perlindungan hanya terpancang pada pasal 285 KUHP saja.Yang pada saat sekarang dinilai tidak sesuai lagi dengan perkembangan masyarakat dan memerlukan pembaharuan. Apabila dibandingkan dengan hukum di luar negeri pelaku perkosaan bisa dijatuhi hukuman mati,tidak seperti di negara kita yang hanya diberi hukuman yang ringan bila dibandingkan dengan dampak yang harus dialami korban.

\section{G. Langkah-Langkah Yang Bisa Diambil Oleh Korban Atau Walinya Apabila Perlindungan Hukum Tidak Terpenuhi}

Bahwa pada saat ini belum ada perlindungan hukum yang khusus atas korban kejahatan perkosaan,sehingga dalam penyelesaian atas perkara tersebut hanya mengacu pada pasal 285 KUHP.Sedangkan dalam perkara pidana kepentingan korban dalam membela kepentingan-kepentingan dan hak-haknya seluruhnya diwakili oleh jaksa penuntut umum dalam persidangan.Sehingga dalam pemutusan perkara oleh hakim bila jaksa penuntut umum sudah merasa puas maka korbanpun sudah diwakilinya termasuk hak untuk melakukan banding.

Dari pemutusan perkara dalam hal perkosaan bila dirasa pada akhirnya nanti korban kurang bisa mendapat perlindungan hukum sebenarnya korban bisa mengajukan gugatan ganti kerugian atas hilangnya keperawanan korban,walaupun sebenarnya hal tersebut tidak dapat nilaiatau dihargai dengan apapun. Gugatan ganti kerugian bisa korban lakukan selambatlambatnya sebelum penuntut umum dalam sidang pengadilan mengajukan tuntutan pidana. Apabila penuntut umum tidak hadir,permintaan ganti kerugian bisa diajukan selambat-lambatnya sebelum hakim menjatuhkan putusan.

Dalam hal gugatan ganti kerugian bisa digabungkan pada tuntutan pidana,supaya perkara gugatan tersebut pada suatu ketika yang sama diperiksa serta diputus sekaligus dengan perkara pidana yang bersangkutan. Tentang gugatan ganti kerugian diatur dalam kitab undang-undang hukum acara pidana 
(KUHAP) Bab XIII pasal 98 yang berbunyi jika suatu perbuatan yang menjadi dasar dakwaan didalam suatu pemeriksaan perkara pidana oleh pengadilan negeri menimbulkan kerugian bagi orang lain,maka hakim ketua sidang atas permintaan orang itu dapat menetapkan untuk menggabungkan perkara gugatan ganti kerugian kepada perkara pidana itu selanjutnya permintaan sebagaimana dimaksud dalam ayat (1) hanya dapat diajukan selambatlambatnya sebelum penuntut umum mengajukan tuntutan pidana.

Dalam hal penuntut umum tidak hadir, permintaan diajukan selambatlambatnya sebelum hakim menjatuhkan putusan. Dalam pasal ini dengan jelas dikatakan bahwa suatu perkara perdata dapat diperiksa bersama-sama dengan perkara pidana dalam suatu sidang pengadilan negeri. Jadi jikalau perbuatan yang menjadi dasar dakwaan dalam suatu perkara yang diajukan oleh penuntut umum di pengadilan negeri menimbulkan kerugian bagi orang lain, maka orang tersebut dapat mengajukan permintaan ganti kerugian dan hakim ketua sidang dapat menetapkan untuk menggabungkan perkara gugatan kerugian itu kepada perkara pidananya. "Kerugian bagi orang lain" termasuk kerugian pihak korban.

Penuntutan ganti kerugian selain digugat secara bersamaan dengan tuntutan perkara pidananya bisa juga denga cara terpisah. Sehingga setelah diputus perkara pidana diajukan lagi perkara perdata dengan gugatan ganti kerugian. Dengan dasar putusan perkara pidana yang mempunyai kekuatan hukum tetap diajukan sebagai dasar untuk menggugat secara perdata dengan gugatan ganti kerugian. Pihak korban bisa mengajukan nilai daripada gugatannya tersebut sesuai dengan keinginannya. Tanpa ada satu patokan yang membatasi secara khusus. Gugatan ganti kerugian bisa diminta oleh korban dalam persidangan. Selain itu penuntut umum juga menuntut penghukuman kepada terdakwa untuk mengganti biaya perawatan di rumah sakit sesuai dengan yang korban keluarkan berdasar kwitansi-kwitansi yang ada, sehingga terdakwa akan dikenakan pembayaran dua kali yaitu pembayaran hukuman penggantian biaya selama korban dirawat di rumah sakit dan pembayaran gugatan ganti kerugian korban secara psikis dengan hilangnya keperawanan korban. 
Atas permintaan korban dengan gugatan ganti kerugian hakim akan mempertimbangkan tentang kebenaran dasar gugatan tersebut serta tentang hukuman penggatian biaya yang telah dikeluarkan oleh pihak korban. Apabila gugatan diyakini mempunyai dasar yang kuat maka hakim akan mempertimbangkannya.

Sedangkan besar dari gugatan korban hakim dalam memutuskan tidak harus selalu harus sesuai dengan yang diajukan oleh korban. Namun hakim akan melihat kondisi serta kemampuan daripada ekonomi terdakwa. Dari dasar kemampuan ekonomi terdakwa tersebut bila dirasakan oleh hakim ia mampu untuk membayar maka hakim akan memutuskan gugatan ganti kerugian kepada korban yang besar nilainya sudah diperhitungkan, hakim dalam memperhitungkan tak akan sampai merugikan kedua belah pihak. Seperti jangan sampai korban mendapat ganti kerugian yang jauh lebih sedikit apabila dibandingkan dengan kerugian yang harus diderita, juga buat terdakwa jangan sampai setewlah hakim memutuskan pembayaran ganti kerugian kepada korban mempunyai kekuatan hukum tetap dan terdakwa harus membayarkan kepada korban, setelah membayarnya terdakwa ternyata tidak akan mempunyai apa-apa lagi sebagai bekal kehidupan keluarga yang ditinggalkan selama menjalani hukuman dan sekembalinya dia nanti setelah keluar dari hukuman.

Apabila pada kenyataannya pelaku pemerkosaan dalam pemeriksaan dinyatakan secara materiil akan mampu untuk membayar gugatan dari pada korban, maka berdasarkan pasal 99 ayat 2 KUHP yang bunyinya "Kecuali dalam hal Pengadilan Negeri menyatakan tidak berwenang mengadili gugatan sebagaimana dimaksud dalam ayat 1 atau gugatan dinyatakan dinyatakan tidak dapat diterima, putusan hakim hanya memuat penetapan hukuman penggantian biaya yang dikeluarkan oleh pihak yang dirugikan." Maka disini korban hanya akan mendapatkan penggantian biaya perawatan selama korban dirawat di rumah korban.

Sedangkan secara moril pun korban mempunyai landasan yang kuat dalam menggugat kerugian kepada pelaku yaitu berdasarkan pasal 1365 Kitab Undang-Undang Hukum Perdata yang bunyinya "Tiap perbuatan yang melanggar hukum dan membawa kerugian kepada orang lain,mewajibkan orang 
yang menimbulkan kerugian itu karena kesalahannya untuk mengganti kerugian tersebut."

Dari hal dapatlah disimpulkan bahwa dikabulkan atau tidak gugatan ganti kerugian oleh hakim,akan diputuskan berdasarkan kemampuan daipada terdakwa.Apabila terdakwa sekiranya mampu membayar maka akan dikabulkan oleh hakim dan sebaliknya apabila sekiranya terdakwa tidak mampu untuk membayar maka gugatan ganti kerugian tersebut juga tidaka akan dikabulkan. Hal inilah yang menjadi kendala bagi korban,karena biasanya pelaku pemerkosaan mempunyai latar belakang ekonomi yang rendah.Sehingga tidah memungkinkan bagi korban untuk mengguggat ganti kerugian oleh korban perkosaan hampir tidak pernah dilakukan,karena dengan peristiwa pemerkosaan tersebut sudah membuat aib yang memalukan bagi korban dan keluarganya,sehingga mereka cenderung menyelesaikan perkara secepatnya supaya tidak semakin diketahui oleh umum yang akan membuat mereka semakin merasa malu.

\section{G. Kesimpulan}

1.Kejahatan perkosaan sangat menimbulkan keresahan dalam kehidupan masyarakat.Apalagi hal tersebut dilakukan terhadap anak-anak yang masih dibawah umur. Dan yang lebih memprihatinkan kejahatan perkosaan tersebut mengakibatkan terganggunya perkembangan mental dan kehidupan korban dimasa depan yang akan terbawa seumur hidupnya. Sehingga kejahatan perkosaan sangatlah dikecam oleh masyarakat. Kejahatan perkosaan terhadap anak dibawah umur terdiri beberapa faktor yang dipengaruhi,antara lain faktor usia,pendidikan,lemahnya penghayatan terhadap agama lingkungan dan faktor kesempatan.Sedangkan di negara kita sampai saat ini belum ada perlindungan hukum yang melindungi secara khusus terhadap korban tindak pidana perkosaan tersebut.Sehingga dalam memberi perlindungan hanya terpancang pada pasal 285 KUHP yang pada saat ini sudah dinilai kurang sesuai lagi dengan kemajuan dan perkembangan masyarakat kita,sehingga perlu adanya perubahan.Mengingat dalam pasal 285 KUHP sanksi yang diberikan dinilai sangat ringan jika dibandingkan dengan penderitan korban yang ditanggung seumur hidup. 
2. Dan apabila korban merasa kurang mendapat perlindungan hukum sebenarnya korban atau walinya bisa mengambil suatu langkah yaitu dengan menggugat terdakwa untuk membayar ganti kerugian kepada korban atas hilangnya keperawanan korban,walaupun hal tersebut tidak bisa dinilai dengan apapun.Berdasarkan pasal 98 KUHAP penggugatan ganti kerugian bisa dilakukan dengan menggabungkan dengan penuntutan pidana,maksudnya ganti kerugian tersebut pada waktu yang sama bisa diperiksa serta diputus sekaligus dengan perkara pidana yang bersangkutan.Gugatan ganti kerugian bisa dilakukan sebelum penuntut umum dalam persidangan mengajukan tuntutan pidananya.Namun pada kenyataannya sampai saat sekarang belum ada korban yang mengajukan gugatan ganti kerugian dalam kasus perkosaan,karena korban secepatnya ingin nmenyelesaikan dan menutup permasalahannya supaya tidak lebih tersiar dan diketahui oleh umum yang akan menambah korban merasa malu.

\section{H. Saran-saran}

Dari kesimpulan tersebut maka penulis menpunyai saran :

1. Perlunya peningkatan upaya untuk mencegah semakin meningkatnya tindak kejahatan.

Dan hendaknya masyarakat sendiri untuk lebih waspada dan berhati-hati terhadap gejala-gejala atas terjadinya kejahatan tersebut untuk turut berperan aktif mengantisipasinya. Selain itu diharapkan para orang tua untuk lebih berhati-hati dan waspada dalam mengawasi putra-putrinya agar tidak terjerumus atau menjadi korban kejahatan perkosaan. Peran aktif penegak hukum dan masyarakat sangatlah diharapkan dalam memberantas pengaruh-pengaruh buruk yang dapat menimbulkan timbulnya kejahatan,antara lain dengan jalan melakukan pengawasan dan penertiban yang ketat terhadap segala hal yang bersifat merangsang dan memancing nafsu birahi. 
2. Hendaknya korban dari kejahatan perkosaan lebih diperhatikan dalam kesehariannya karena trauma yang mereka alami sangat berat dan memerlukan waktu untuk melupakan segala hal yang menimpanya,juga keluarga dan masyarakat dapatlah menerima secara wajar dan tidak mengucilkan atau menyepelekan korban tersebut.

\section{DAFTAR PUSTAKA}

Nanada Agung Dewantara,Kemampuan Hukum Pidana dalan menanggulangi Kejahatan-kejahatan baru yang berkembang dalam masyrakat, Liberty,Yogjakarta 1988.

Sudarto Hukum dan Hukum Pidana,Alumi Bandung 1986

I.Nyoman Nurjaya,Segenggam Masalah Aktual Tentang Hukum Acara Pidana dan Kriminolog, Bina Cipta Bandung

Moeyatno,Kitab Undang-undang Hukum Pidana,Bina Aksara,Jakarta

Soerjono Soekamto,Kriminolog Suatu Pengantar,Ghhalia Indonesia,Jakarta 1981

B.Simanjuntak,Pengantar Kriminolog dan Patologi Sosial,Tarsito,Bandung 1991

Soedjono D,Penanggulanagan Kejahatan,Alumi Bandung 1993

Kartini Kartono,Patologi Jilid I,Rajawali Jakarta 1997

R.Soesilo,Kitab Undang-undang Hukum Pidana Serta Penjelasannya

Shanti Dellyana,Wanita dan Anak di mata Hukum Liberty, Yogjakarta

Daryanto S.S Kamus Besar Bahasa Indonesia lengkap,Apollo Surabaya

Wiroyo Prodjodikoro,Tindak Tanduk Pidana Tertentu di Indonesia,PT.Rafika Aditama,Bandung,2002

H.Hilman Hadikusuma,Hukum Perkawinan Indonesia,CV Mandar Maju,Bandung 1990

Hasan Sadily,Sosiologi Masyarakat Indonesia,PT Pembangunan Jakarta,1997

WA.Bonger,Pengantar Tentang Kriminolog,Terjemahan RA. Koesnoen,PT Pembangunan dan Galia Indonesia,Jakarta 1982 